\title{
Water Management through Canal Blocking to Improving Rice Productivity in Langsat Permai Village, Bunga Raya District, Siak Regency, Riau Province
}

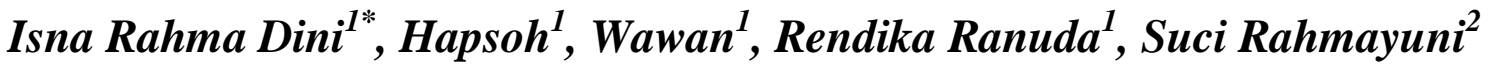 \\ ${ }^{1}$ Department of Agrotechnology, Faculty of Agriculture, Universitas Riau \\ ${ }^{2}$ Department of Sociology, Graduate School Faculty of Social Science and Politics, Universitas Riau
}

\begin{abstract}
The low productivity of paddy in Langsat Permai Village, Bunga Raya District, Siak Regency, could becaused by the unavailability of sufficient water for crop cultivation. Therefore, it is necessary to make water management by making canal blocking to be used on rice plants in the area. Canal blocking that are built expected to help meet the water needs of rice plants during the dry season. Based on these problems, then accompaniment is provided through water management in Langsat Permai Village, Bunga Raya District, Siak Regency. Mentoring strategies are carried out by discussing about the impact of making canal blocking directly to farmer groups. Through this activity, the availability of water for rice plants during the dry season is fulfilled. Production of $1 \mathrm{Ha}$ of rice before the blocking canal produced was 4-5 tons/harvest and the production increased to 6-7.8 tons/harvest after the canal blocking.
\end{abstract}

Keywords: Canal Blocking, Water Management, Dry Season

Abstrak. Rendahnya produktivitas tanaman padi di desa Langsat Permai Kecamatan Bunga Raya Kabupaten Siak salah satunya disebabkan karena belum tersedianya air yang cukup untuk budidaya tanaman. Oleh karena itu, perlu dilakukan pengelolaan tata air dengan pembuatan kanal bloking untuk dapat dimanfaatkan pada tanaman padi di daerah tersebut. Kanal bloking yang dibangun diharapkan dapat membantu memenuhi kebutuhan air pada tanaman padi saat musim kemarau. Berdasarkan permasalahan tersebut maka dilakukan pendampingan melalui pengelolaan tata air di Desa Langsat Permai Kecamatan Bunga Raya Kabupaten Siak. Strategi pendampingan dilakukan dengan berdiskusi secara langsung dengan kelompok tani mengenai dampak pembuatan kanal bloking. Melalui kegiatan ini ketersediaan air untuk tanaman padi pada musim kemarau terpenuhi. Produksi 1 Ha padi sebelum

\footnotetext{
*Corresponding author at: Pekanbaru-Riau, 28293

E-mail address: isnarahmadini19@gmail.com
} 
adanya kanal bloking menghasilkan 4-5 ton/panen menjadi 6-7,8 ton/panen setelah adanya kanal bloking.

Kata Kunci: Kanal Bloking, Tata Air, Musim Kemarau

Received 14 October 2018 | Revised 1 April 2019 | Accepted 4 April 2019

\section{Introduction}

Riau Province is one of the provinces that develop more palm oil plantations than food crops. The available land in Riau Province hasbeen converted into agricultural land, because of the mindset of the Riau community which stated that the plantation business, especially oil palm, is more profitable than food crops. Furthermore, the paddy crop index only once a year, so that it is less profitable to develop food crops. The food, especially rice, needs in Pekanbaru are still imported from the neighboring province of West Sumatra. Therefore, to meet the needs of the people in the Province of Riau itself, they need to be made to encouraged to develop food and horticultural business in various regions of Riau.

Langsat Permai Village is one of the villages in Bunga Raya Subdistrict which has the potential to develop food crops and horicultural plants. Some of the land in Langsat Permai has been cultivated either for food crops or for plantation crops. However, in recent years, the people of Langsat Permai have switched to develop food crop cultivation.

The availability of sufficiently optimal land for development of food crop cultivation caused the village become the location to developing food crops for several types of food crops such as rice, corn, long beans, and cassava. Of these, the most widely cultivated food crops are rice. The local village community has grown rice in 102 hectares of rice paddy with a productivity of 255 tons/ha or in other words can produce 2.5 tons in 1 ha of rice fields.

The need of water for rice plants in Langsat Permai Village has not been supplied optimally because water is enough to irrigate the cultivated rice fields. The unavaibility of water problem will be even worse if the planting is done in the dry season, causing the farmers experience difficulties in providing water, so that course can affect the inhibition of agricultural businesses in the village. There is a need to overcome the problem of water needs, by developing good water management.

Around the cultivated land in Langsat Permai there is a canal that is only allowed to flow and has not been used for so long, so that the canal blocking is necessary to be made. The flow of water in the canals around is given a divider so that the water is collected. Then, the farmers can be used it for rice plants and other crops to with using a pump water. Through good water management, food crops, especially rice, can grow leading to the income increase of the people in the village. Improving the water management will thencan indirectly change the mindset and 
knowledge of the farming community in Langsat Permai Village to further develop food crops compared to oil palm. Consequently, canal blocking effort support the increased of rice production and provide additional benefits to the community of Langsat Permai Village, Bunga Raya District, Siak Regency.

The average of rice consumption in Indonesia is $98 \mathrm{~kg} / \mathrm{capita} / \mathrm{year}$ [1], and the total need for rice is 79.1 million tons/year [2]. Population growth increases the need for rice, therefore the increase of rice production is very important to meet these needs. The production rice can be achieved by with Salibu technology through the use of integrated organic fertilizers and pesticides [3] and good water management.

Wetland rice water management is very important to maximize the development of rice cultivation technology, especially to improve the efficiency of water use. According to [4], fluctuations in water availability are a problem in rice growth and sufficient water is an advantage for the growth of paddy rice plants.

\section{Method}

The activity was carried out in Langsat Permai Village, Bunga Raya District, Siak Sri Indrapura District, Riau Province. The materials used in this study was questionnaires. The tools used are cameras, label paper, plastic, cutter knives, ropes, rulers and stationery.

\section{Results and Discussion}

The service was carried out in Langsat Permai Village, Bunga Raya District because the agricultural production of food crops, especially rice, was not optimal. The making of canal blocking is intended to meet the need of water for food agriculture activities, especially rice. Making canal blocking is very effective to provide water in the dry season so that the farmers can grow the rice properly.

Following the figure of canal blocking has been built and ready to use by the community so that it can be used for cultivation of paddy rice plants (Figure 1). Then, the management of canal blocking utilization is described through a map explaining the scheme of drainage of water from the peat swamp forest water and will then be used for rice paddy cultivation can be seen Figure 2. 


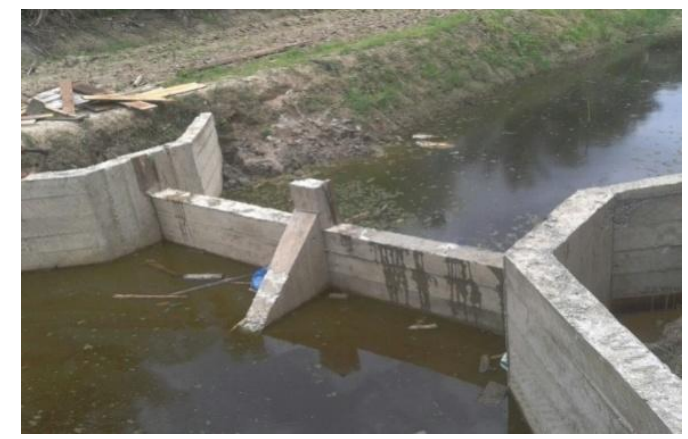

Figure 1. Canal blocking is ready to use for water

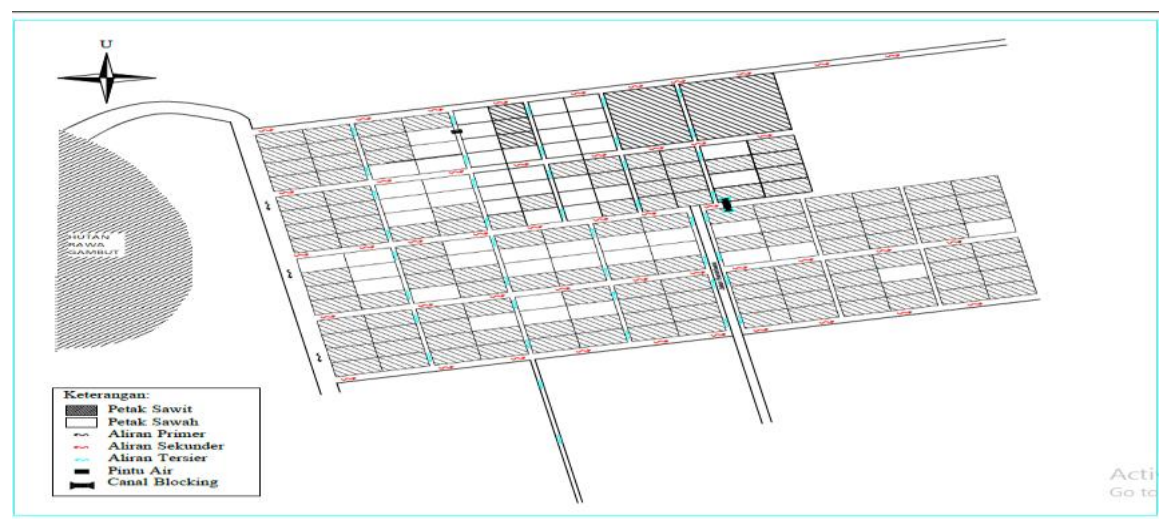

Figure 2. Water governance through canal blocking

The water management in the form of canal blocking elevate the rice plant growth as shown in Figure 3. The availability of water make a good influence on the color of the leaves up to rice tillers. Proper water management will accelerate the improvement of paddy productivity by increasing the growth of lowland rice.

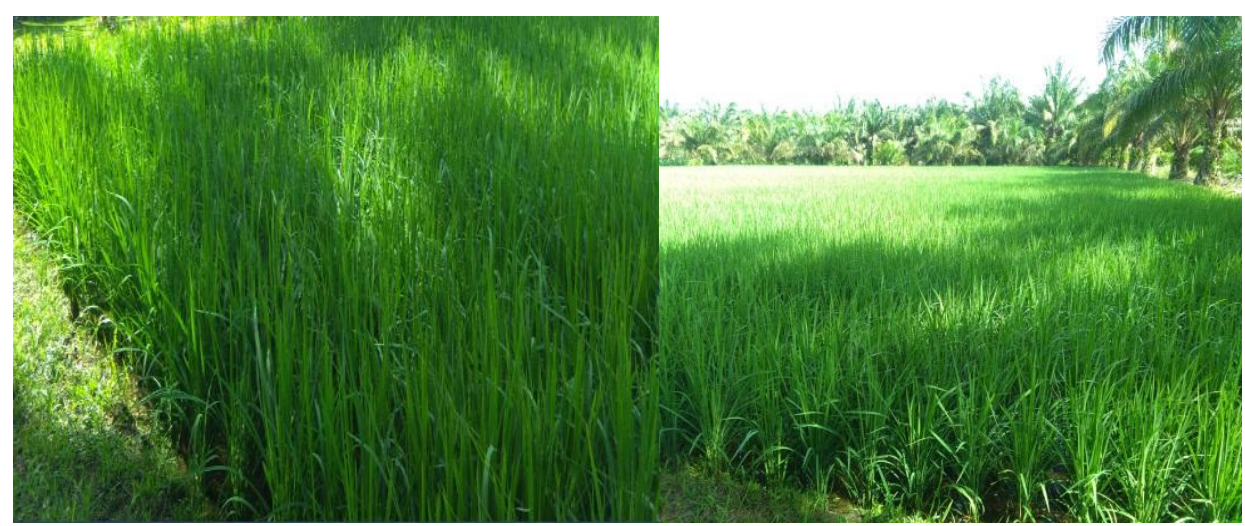

(a)

(b)

Figure 3. Rice in the vegetative phase before the canal (a) and after the canal (b) 
The effect of water availability can be seen in both the vegetative phase, plant height and number of tillers, and in the generative phase, the number of productive tillers and panicle weight per plant clump. The differences in panicle of paddy fields before and after the canal blocking can clearly be seen in Figure 4. which shows differences in panicle of paddy fields before and after the canal.

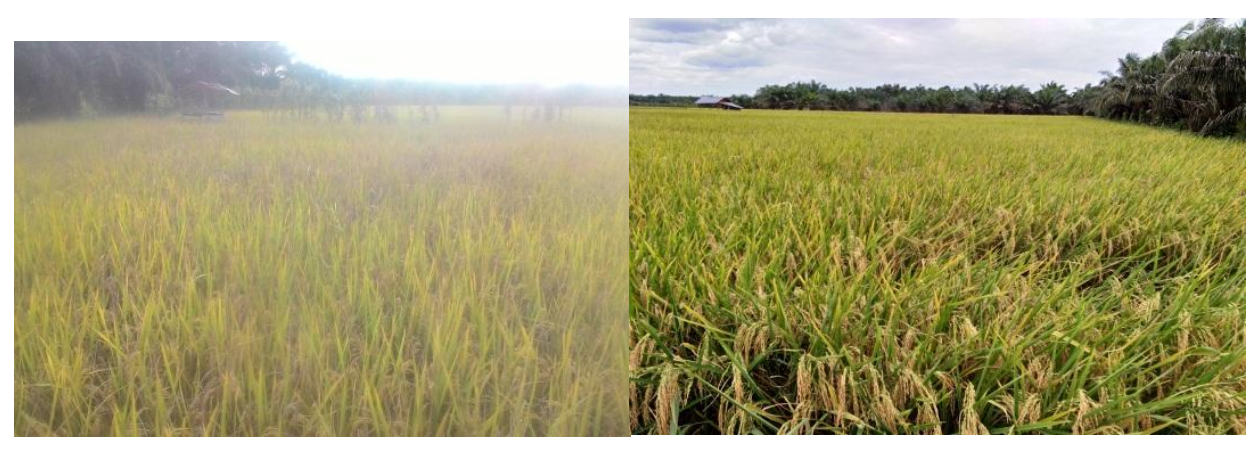

(a)

(b)

Figure 4. Rice pan before the canal (a) and after the canal (b)

Based on the Figure 4 showed that the productivity rice before and after availability the canal blocking is defferent, like the number of panicles is less than after there is a canal, the leaf color is greener than before. Therefore, the canal indicates the influence of the availability of water in the cultivated land. This is in accordance with the opinion [4] that good irrigation for the optimization of growth and production in rice plants has a significant effect on plant height and dry grain weight.

In term of rice harvesting, the production was only 4-5 tons per hectare in one crop, while the production has increased up to 6-7.8 tons per hectare for one crop after the canal blocking. Moreover, the water remains available as a requirement in the cultivation system in the dry season. This increase in agricultural yields will also have an impact on the social and economic community of Langsat Permai Village.

\section{Conclusion}

The availability of water with the canal blocking is very beneficial for farmers. They were solely depend on the rainy season for rice planting systems, and the canal enable them to farm during dry season. The rice productivity before canal blocking was 4-5 tons per hectare and has been enhanced to 6-7.8 tons per hectare leading to the increase the community's economy in Langsat Permai Village.

\section{Acknowledgment}

The authors would like to thank the Ministry of Research, Technology and Higher Education through the 2017 Science and Technology Program for Mitra Villages for funding this activity. 


\section{References}

[1] Badan Pusat Statistik. 2015. Kebutuhan Pangan Nasional. https://bps.go.id/Kebutuhan-Pangan-Nasional.hmtl. Diakses tanggal 25 September 2018.

[2] Kementerian Perdagangan. 2017. Laporan Rapat Kerja Kementerian Perdagangan. Kedaulatan Pangan Nasional. Jakarta.

[4] Mayly, S and A. Syafri. 2018. Implementetion of Salibu Rice Cultivation Technology in Percut Sei. Tuan Sub-District. Journal of Saintech Transfer (JST) 1 (1): 33-40.

[4] Ezward, C., S. Effendi, and J. Makmun. 2018. Pengaruh Frekuensi Irigasi terhadap Pertumbuhan dan Hasil Padi. Jurnal Agroteknologi Universitas Andalas 1 (1): 17-24. 